\title{
DEVELOPING ONLINE LEARNING VIDEO BASED ON THE SCIENCE TECHNOLOGY SOCIETY (STS) TO IMPROVE BIOLOGY LEARNING OUTCOMES
}

\author{
Tuti Handayeni, I Putu Artayasa*, and Dewa Ayu Citra Rasmi \\ Biology Education Department, FTTE, University of Mataram, Mataram, Indonesia \\ *Email: artayasa75@unram.ac.id
}

Acceped: July 27 2021. Approved: August 02 2021. Published: Sept 042021

\begin{abstract}
This research aims to determine the validity of online learning video based on the Science Technology Society (STS) and its effect on biology learning outcomes at SMA 1 Labuapi. The type of research is research and development with the ADDIE model. The research sample was class X students at SMA 1 Labuapi with as many as 12 students for the control class and 15 students for the experimental class. Research data obtained from learning outcomes tests (post-test scores) on environmental change material. The results of data analysis showed that the level of validity of the developed video obtained a percentage of $84 \%$ in terms of media which include very valid criteria and $86 \%$ in terms of material which include very valid criteria. The results of data analysis of learning outcomes data showed that there was a difference in the average post-test score between the experimental class through the application of learning using video which combined with the STS approach and the control class through the application of conventional learning. The average score of the post-test in the experimental class was 84.23 , while the average score of the post-test in the control class was 67.17. The significance value of two independent sample t-test obtained is 0.002 , the significance value obtained is smaller than 0.05 (p-value < 0.05), so Ho is rejected. The conclusion of this research that the video developed has very valid criteria and the application of learning using video based on the science technology society (STS) approach has a significant effect on improving biology learning outcomes at SMA 1 Labuapi.
\end{abstract}

Keywords: learning video, science technology society, student biology learning outcomes.

\section{INTRODUCTION}

Education in the new normal era is experiencing major obstacles in its implementation caused by the Covid-19 pandemic, so offline learning in the classroom cannot be carried out optimally. The Covid-19 pandemic has changed various aspects of human life today, including in the world of education which requires all elements of education to be able to adapt to the online learning process [1]. Online learning allows learning to be done anytime and anywhere. However, in its implementation there are many obstacles experienced by both teachers and students.

The implementation of online learning is not all going well. There are several obstacles faced, especially by schools located in remote areas, such as limited internet access. Another obstacle is the number of assignments that are not balanced with a complete explanation of the material which is often a complaint in online learning [2]. Therefore, the learning process carried out online should minimize these obstacles so that learning can be implemented effectively and efficiently.

One example of the ineffectiveness of implementing online learning occurs at SMA Negeri 1 Labuapi which is one of the high schools in West Lombok Regency, West Nusa Tenggara Province. During the Covid-19 pandemic, the school's students implemented online learning from each student's home or often called Learning From Home (LFH). The lack of effectiveness of online learning in schools is caused by various problems, such as: 1) lack of understanding of teachers related to learning technology, so that the implementation of online learning is monotonous which only relies on WhatsApp and Google Classroom application features, while the use of Zoom is still not implemented properly; 2) lack of enthusiasm and discipline of students learning during online learning, such as filling in attendance lists and sending student assignments that are not on time; and 3) students' weak understanding of the teaching materials they have learned independently, so that the subject matter that has been delivered by the teacher in online learning needs to be repeated during offline learning.

Based on the results of interviews with biology subject teachers, the main problem in learning at SMA Negeri 1 Labuapi is the low motivation and student learning outcomes. The low student learning outcomes are indicated by the results that have not reached the Minimum Completeness Criteria (MCC). The MCC that has been set by the school for biology subjects is 75 . The results of the mid-semester assessment showed that out of 43 students, 28 students had not achieved the MCC score. Low learning outcomes are caused by the low understanding of students regarding learning materials delivered online. This is a result of too many assignments, causing students to get bored of learning, and the instructions given by the teacher in online learning are factual, only in the form of sentence descriptions so that the message conveyed becomes less attractive and less effective. 
Biology learning is a transfer of knowledge from learning resources in the natural environment that is facilitated by the teacher [3]. The way of expressing biological objects is inseparable from the scientific method which includes a scientific way of thinking and acting through a series of scientific work processes. In learning biology, students are expected to acquire knowledge and skills to study biological objects, find facts, and build concepts and principles of biological science through observation [4]. One of the approaches used to make biology learning contextual, enabling students to find facts and build concepts is the Science Technology Society (STS) approach.

The Science Technology Society (STS) approach is a learning approach that raises issues encountered by students in the community into learning and relates them to existing science concepts [5]. Students are trained to integrate their understanding of the natural world (science) with the man-made world (technology) and the social world through students' everyday experiences. The implementation of the STS approach can improve the quality of student activities, student learning outcomes, and the quality of students' scientific and technological literacy as well as increase student and teacher interactions during the learning process [6]. One of the biological materials related to science and technology is the subject of environmental change. Environmental change is a concept that has the characteristics of discussing the natural surroundings. In the subject matter of environmental change, it does not only include discussion of subject matter that must be memorized, but also involves developing skills in addressing problems that occur in the environment [7].

During the Covid-19 pandemic, skill development activities such as discussions, practicums, study tours, and others were not carried out properly due to the limited learning process. The solution to this problem is to use learning videos based on the STS approach. With learning videos based on the STS approach, students can find out the process of these skills development activities even though the learning process is limited to being carried out in the classroom. Learning videos are expected to be able to improve students' skills and understanding of subject matter that requires a lot of explanation, for example by developing video tutorials from practicum stages.

The use of video media in learning at SMA Negeri 1 Labuapi is rare, because teachers have difficulty in choosing suitable videos to be shown to students. In addition, technical obstacles are also very common, so teachers tend to only choose the lecture method with powerpoint slides (PPT) as a support for learning media.

Referring to the learning problems that have been mentioned above, it is necessary to have a learning innovation that integrates the STS approach into learning videos as an effective biology learning medium. Video media is able to communicate information and knowledge that describes an ongoing process or procedure. The use of learning videos is expected to help students to understand the concept of learning well so as to improve learning outcomes [8]. Therefore, a study was conducted that aims to develop online learning videos that apply the Science Technology Society (STS) approach to improve biology learning outcomes at SMA Negeri 1 Labuapi.

\section{RESEARCH METHODS}

The type of research used was Research and Development ( $R$ and $D$ ) with the ADDIE model (Analysis, Design, Development, Implementation, and Evaluation). The stages of this research are presented in Figure 1.



Figure 1. ADDIE Model Research Stages

The research was conducted in the even semester of the 2020/2021 academic year in May 2021 at SMA Negeri 1 Labuapi. The population of this study were students of class $X$ at SMA Negeri 1 Labuapi which consisted of 2 classes, namely class X IPS and X IPA. Based on the results of the lottery, in this study, class X IPS was used as the control class and X IPA as the experimental class.

Data was collected through interviews, questionnaires, observation sheets and tests. Interviews were conducted with class $\mathrm{X}$ biology teachers at SMA Negeri 1 Labuapi. The questionnaire used in the form of a subject matter expert validation questionnaire, media expert validation, student and teacher response questionnaires. The observation sheet was filled in by the researcher during the learning process. The test used was a multiple choice test with 15 questions. After being validated by subject matter and learning media experts, the video was then used in learning with the topic of environmental change in class X SMA Negeri 1 Labuapi. During learning, researchers filled out observation sheets based on observations of the learning process using video. At the end of the learning activity, students were given the test. After that, the 
teacher and students filled out a questionnaire to find out their response to the use of video in the learning process.

Analysis of research data was using SPSS 17.0. The hypothesis test used was a two-sample ttest at alpha 0.05. Before analyzing the data using the $t$ test, the research data were first tested for normality and homogeneity as a prerequisite for the $\mathrm{t}$ test. Testing the normality of the data was using the Kolmogorov-Smirnov test, while the homogeneity test used the Levene's test. The t-test aims to determine whether or not there is a significant difference between the two sample means [9].

\section{RESULTS AND DISCUSSION}

\section{Development Research Results}

The development of learning videos is a process to design and produce videos that will be used in learning based on existing development theories. This study uses the ADDIE development model (Analysis, Design, Development, Implementation, and Evaluation). This model can be used for various forms of product development such as models, strategies, methods, teaching materials and learning media. The ADDIE model was developed by Dick and Carry to design a learning system [10]. The selection of this model is based on the consideration that the ADDIE model is easy to understand because of its systematic and flexible structure.

Research with the ADDIE model includes five stages. The first stage is analysis. At this analysis stage, information was obtained about the low learning outcomes of students in class X SMA Negeri 1 Labuapi, especially in learning biology. This is because during the Covid-19 pandemic, online learning was not implemented optimally, both in terms of the number of interactions between teachers and students and the amount of learning material delivered by the teacher.

Thus, teachers need to maximize the use of learning media during a pandemic because it plays an important role in helping students understand abstract biological material, as well as helping students learn in new situations during this pandemic [11]. During online learning, it is necessary to have learning media that can help students learn independently anytime and anywhere to complement the subject matter delivered by teachers online, especially in biology learning which incidentally has a wide range of subject topics. So far, the learning media innovation has not been carried out by the biology teacher at the school, so in this study, a practical, efficient, and effective learning video was developed to help students understand the concept of biology well.

The video media developed is expected to be an effective learning media applied during the Covid-19 pandemic. Learning video media can help activate students' hearing and vision which are then transferred to the brain so that students can capture information well. The use of video in learning also creates interest for students and gives the impression of being fun and easy for students to understand [12].

The second stage is the design stage, where appropriate strategies are designed to develop learning videos. The learning video developed is based on the Science Technology Society (STS) which gives students the opportunity to see problems in the community and find solutions to these problems through the application of technology. The STS approach is a way to train and teach students so that accepted scientific concepts can be applied to overcome the problems they face in society [13]. Therefore, the development of learning videos that are integrated with the STS approach is carried out to make it easier for students to understand concepts and solve real problems in the surrounding environment.

The development stage is the third stage in the ADDIE model development procedure. At this stage, the design that has been made is realized by utilizing various video-making applications. After the learning video is ready, the next stage is validation by media and subject matter experts. This stage is important because an assessment by an expert or validator provides an assessment of how the quality of the video is and helps improve existing weaknesses. Based on the validation results, media experts gave an assessment of $82 \%$, while subject matter experts gave a score of $86 \%$. The score indicates that the learning videos that have been developed are in very valid criteria, so that the videos can be used in the learning process in the classroom.

The implementation stage is the fourth stage and at this stage the videos that have been developed are ready to be used in learning with the topic of environmental change. Learning using STS video is applied to the experimental class. Through the STS approach students can relate the subject matter to everyday life as well as relevant technological developments so that students' interest in science can increase [14].

Another result of this study is the teacher's response to the learning video by giving a score of 52 with a validity percentage of $86 \%$ which is included in the very valid criteria. Meanwhile, 21 students gave a score of 850 with a validity percentage of $81 \%$ which was included in the very valid criteria. The validity of the learning video is also supported by the results of observations of the learning process. During learning using videos combined with the STS approach, it shows that students actively participate in discussions. Based on the results of observations, the learning implementation score was $84 \%$ which showed a very good category. 
The last stage is evaluation. At the evaluation stage, revisions or improvements are made to improve the quality of the videos that have been developed. At the development stage, the validator provides some notes as suggestions or input even though the video has been declared very valid. Based on the validator's suggestion, it is necessary to improve several displays such as the character of the teacher, environmental conditions and add several important components and evaluations in the video so that the revised video can be used in learning with the topic of environmental change in the future with better results.

\section{Quasi Research Results}

Student learning outcomes data were obtained from test results at the end of the learning process or post-test control class and experimental class. Based on the results of data analysis, there are different average learning outcomes between the control class and the experimental class. In the control class, from the respondents as many as 12 students obtained an average of 67.17 while the experimental class obtained an average of 84.23 from 15 students. The comparison of the post-test mean also shows that the learning outcomes in the experimental class are higher than the control class with a difference of 17.06. The average difference can be visualized by the graph in Figure 2 .

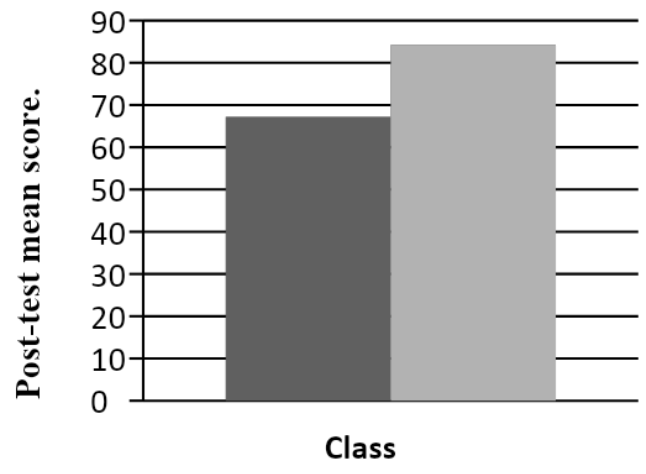

Figure 2. The difference in the average learning outcomes of the control class (left) and the experimental class (right).

The results of the normality test using the Kolmogorov-Smirnov formula are presented in Table 1. The data can be said to be normally distributed if the significance value is more than 0.05 (p-value > $0.05)$. Table 1 shows that the normality test of learning outcomes in the control class reached a significance value of 0.200 , while the experimental class had a significance value of 0.057 . Based on the results of the normality test, the data on the learning outcomes of the control class and the experimental class were normally distributed.
Table 1. Normality Test

\begin{tabular}{ccccc}
\hline \multirow{2}{*}{ Class } & \multicolumn{3}{c}{ Kolmogorov-Smirnov } \\
\cline { 3 - 5 } & & Statistic & df & Sig. \\
\hline \multirow{2}{*}{ Learning } & Control Class & 0.174 & 12 & 0.200 \\
Outcomes & $\begin{array}{c}\text { Experiment } \\
\text { Class }\end{array}$ & 0.216 & 15 & 0.057 \\
\hline
\end{tabular}

The results of the homogeneity test using Levene's formula are presented in Table 2. The data can be said to have a homogeneous variance if the significance value is more than 0.05 (p-value > 0.05). Table 2 shows that the homogeneity of the variance of post-test learning outcomes in the control class and experimental class has a significance value of 0.984 . Based on the results of the homogeneity test, it was obtained that the data on the learning outcomes of the control class and the experimental class were homogeneous.

Table 2. Homogeneity Test

\begin{tabular}{lccc}
\hline \multicolumn{4}{c}{ Learning Outcomes } \\
\hline Levene & df1 & df2 & Sig. \\
\cline { 2 - 4 } Statistic & 1 & 25 & 0.984 \\
\hline
\end{tabular}

The results of the hypothesis test using the t-test of two independent samples are shown in Table 3. The results of the test show the value of $\mathrm{t}=3.404$ with a significance value of 0.002 . Based on the results of the t test, Ho is rejected and $\mathrm{Ha}$ is accepted. In other words, the results of the study indicate that the application of learning using video based on the Science Technology Society (STS) approach has a significant effect on student biology learning outcomes at SMA Negeri 1 Labuapi. Based on the acquisition of an average value of the experimental class which is higher than the control class, it means that the application of learning videos based on the STS approach causes a higher increase in learning outcomes than without the application of videos based on the STS approach.

Table 3. Results of t-test of two independent samples

\begin{tabular}{ccccccc}
\hline & \multicolumn{5}{c}{ t-test for Equality of Means } \\
\cline { 2 - 6 } & $\mathrm{t}$ & $\mathrm{df}$ & $\begin{array}{c}\text { Sig. } \\
(2- \\
\text { tailed) }\end{array}$ & $\begin{array}{c}\text { Mean } \\
\text { Differ } \\
\text { ence }\end{array}$ & $\begin{array}{c}\text { Std. Error } \\
\text { Difference }\end{array}$ \\
\hline $\begin{array}{c}\text { Equal } \\
\text { variances } \\
\text { assumed } \\
\begin{array}{c}\text { Equal } \\
\text { variances } \\
\text { not }\end{array}\end{array}$ & 3.404 & 25 & 0.002 & 17.067 & 5.013 \\
assumed & 3.409 & 23.8 & 0.002 & 17.067 & 5.006 \\
\hline
\end{tabular}


The results of data analysis showed that there was a difference in the post-test mean in the two classes, where the experimental class had a higher average than the control class with a difference of 17.06. This shows that the use of learning videos based on the STS approach is more effective than conventional learning. This result is in line with the results of a study conducted by Rinajayani [15] which measured the seriousness of student learning activities using videos and obtained a score of $79 \%$ in the first learning and $83 \%$ in the second learning. This indicates that the video shown makes students enthusiastic to pay attention to the messages in the video, thereby increasing students' understanding of the topics they are studying.

The application of the STS approach causes the experimental class students to actively participate in the learning process; this can be observed when students participate in group discussions. They are able to work with group members, answer questions well, and respect differences of opinion. This is in line with the opinion of Majas [16] that the application of the STS approach is very effective in improving science process skills and activeness in learning. In this approach, the teacher as a learning facilitator makes efforts to overcome learning problems in the classroom so that students are actively involved so that they can have a positive influence on their learning outcomes [17]. Showing a video that lasts approximately 10 minutes and the application of the STS approach is able to direct students effectively in achieving learning objectives.

Learning outcomes are influenced by two factors, namely individual factors and social factors. Individual factors include maturity or growth factors, intelligence, training, motivation and other personal factors. Social factors are factors that exist outside the individual, such as family, teachers and their teaching methods, learning infrastructure, environment and available opportunities [18]. These two factors play an important role in influencing each other so that teachers need to pay attention to these factors when starting learning. The application of learning videos based on the STS approach is included in the category of external factors because it is related to the media and methods used by teachers in teaching and learning activities. So that the use of video and the application of the STS approach need to be the main choice in learning

Video media is considered effective in improving student learning outcomes because it has elements of sound, images, and animations that attract students' motivation to learn. There are 3 characteristics of media that increase students' motivation and learning outcomes, namely: 1) having more than one media that is convergent by combining audio and visual elements; 2) interactive, which has the ability to accommodate user responses; and 3) independent, in the sense of providing convenience and completeness of content so that it can be used without the guidance of others [19].

The student-centered learning process places students at the heart of the learning process by appreciating the diversity of potentials of each student by involving them directly in the learning process [20]. By combining video and the STS approach, it is not only presenting a different learning experience, but can indirectly train students in the process of thinking, communicating, working together, and respecting opinions so that they can develop student competence.

\section{CONCLUSIONS}

Based on the results of research and discussion, it can be concluded that the use of learning videos based on the STS approach in learning biology has an effect on learning outcomes at SMA 1 Labuapi. The application of the video based on the STS approach causes an increase in learning outcomes that is higher than the application of conventional learning, so that the application of video media is more effective than the application of conventional learning.

Based on the results of the research, recommendations that can be given are that in further development research it is recommended to consider the time needed, because the stages of development research, from the analysis stage to the evaluation of product development take a long time to get optimal results. In addition, research using learning videos also needs to be applied to other biology learning topics because the scope of biology material is very wide and has varied characteristics. Further researchers must have basic skills in video development so that the resulting learning videos can be conceptualized properly. This study only focuses on cognitive learning outcomes, so it is recommended for further research to examine the application of learning videos to other learning outcomes, namely the affective, psychomotor, and student motivation aspects.

\section{REFERENCES}

[1] Herliandry, L. D., Nurhasanah, Suban, M. E., dan Heru, K. (2020). Pembelajaran pada Masa Pandemi Covid-19. Jurnal Teknologi Pendidikan, 22(1), 65-70.

[2] Gusty, S., Nurmiati, Muliana, Sulaiman, O. K., Ginantra, N. L. W. S.R., Manuhutu, M. A., Sudarso, A., Leuwol, N. V., Apriza, Sahabuddin, A. A., Hastuti, P., Setianto, A. Y., Metanfanuan, T., Uktolseja, L. J., Jamaluddin, Gaspersz, S., Karwanto, Bungin, E.R., \& Warella, S. Y. (2020). Belajar Mandiri: Pembelajaran Daring di 
Tengah Pandemi Covid-19. Medan: Yayasan Kita Menulis.

[3] Santosa, P. (2018). Mahir Praktikum Biologi: Penggunaan Alat-Alat Sederhana dan Murah untuk Percobaan Biologi. Yogyakarta: Deepublish.

[4] Agustina, P., \& Saputra, A. (2012). Problematika Pelaksanaan Pembelajaran Biologi Berbasis Kecakapan Hidup (Life Skill) di Indonesia. Seminar Nasional IX Pendidikan Biologi FKIP UNS, 9(1), 310-316.

[5] Susanto, A. (2014). Pengembangan Pembelajaran IPS di Sekolah Dasar. Jakarta: Prenada Media Group.

[6] Jailani, J., Abubakar, A., \& Anwar, A. (2018). Implementasi Pendekatan Science Technology Society (STS) pada Materi Pokok Lingkungan Hidup sebagai Upaya Peningkatan Life Skill Siswa. Jurnal Serambi Ilmu, 19(2), 132-141.

[7] Fitri, J., Sa'adah, S., \& Yusup, I. R. (2019). Penguasaan Konsep Siswa pada Materi Ekosistem Melalui Penerapan Model Problem Posing Learning Berbasis Dongeng Sains (PPL-DS). Jurnal BioEdUIN, 9(1), 63-70.

[8] Pribadi, B. A. (2017). Media dan Teknologi dalam Pembelajaran. Jakarta: Kencana.

[9] Prayadnya, I. P. A. A., \& Jayantika, I. G. A. N. T. (2018). Panduan Penelitian Eksperimen Beserta Analisis Statistik dengan SPSS. Yogyakarta: Deepublish.

[10] Mulyatiningsih, E. (2012). Modul Kuliah Pengembangan Model Pembelajaran. Yogyakarta: Universitas Negeri Yogyakarta.

[11] Tasyari, S., Putri, F. N., Aurora, A. A., Nabilah, S., Syahrani, Y., \& Suryanda, A. (2021). Identifikasi Media Pembelajaran pada Materi Biologi dalam Meningkatkan Pemahaman Konsep Peserta Didik di Masa Pandemi Covid19. BIOEDU Jurnal Pendidikan Biologi, 6(1), 1-8.

[12] Salsabila, U. H., Sofia, M. N., Seviarica, H. P., \& Hikmah, M. N. (2020). Urgensi Penggunaan Media Audiovisual dalam Meningkatkan Motivasi Pembelajaran Daring di Sekolah Dasar. Insania, 25(2), 284-30.

[13] Dewi, N. N. P. K., Ardana, I. K., \& Kristiantari, M. G. R. (2014). Pengaruh Pendekatan STS (Science Technology Society) Berbasis Portofolio terhadap Hasil Belajar IPS Siswa Kelas IV SD Gugus Melinggih Payangan Gianyar Tahun Ajaran 2013/2014. Jurnal Mimbar PGSD Universitas Pendidikan Ganesha, 2(1), 1-10.

[14] Marwah, D., Wahyudin, D., \& Cynthia R. (2017). Efektivitas Penerapan Model Pembelajaran Science Technology and Society (STS) Terhadap Peningkatan Kemampuan Berpikir Tingkat Tinggi. Jurnal Edutechnologia, 3(2), 1-12.
[15] Rinajayani. (2013). Penggunaan Media Video untuk Meningkatkan Pemahaman Konsep Ilmu Pengetahuan Sosial pada Siswa Kelas IV SD Bantul Timur Tahun Pelajaran 2012/2013. Skripsi. Yogyakarta: Fakultas Ilmu Pendidikan Universitas Negeri Yogyakarta.

[16] Majas, N. (2016). Pengaruh Pembelajaran Sains Teknologi Masyarakat (STM) terhadap Keterampilan Proses Sains pada Materi Termokimia Siswa Kelas XI SMAN 1 Simpang Kiri. Skripsi. Banda Aceh: Fakultas Tarbiyah dan Keguruan Universitas Negeri Ar-Raniry.

[17] Prilliza, M. D., Lestari, N., Merta, I. W., \& Artayasa, I. P. (2020). Efektivitas Penerapan Model Discovery Learning terhadap Hasil Belajar IPA. Jurnal Pijar MIPA, 15(2), 130-134.

[18] Syahputra, E. (2020). Snowball Throwing Tingkatkan Minat dan Hasil Belajar. Sukabumi: Haura Publishing.

[19] Irwanto \& Guswiani, W. (2019). Efektivitas Penggunaan Video Pembelajaran dalam Meningkatkan Motivasi dan Hasil Belajar Siswa dalam Pembelajaran Front Office di Kelas XI Akomodasi Perhotelan SMKN 3 Garut. Jurnal Literasi, 10(2), 77-91.

[20] Suwarjo, Maryatun, I. B., \& Kusumadewi, N. (2012). Penerapan Student Centered Approach pada Pembelajaran Taman Kanak-Kanak Kelompok B (Studi Kasus di Sekolah Laboratorium Rumah Citta). Jurnal Pendidikan Anak, 1(1), 79-102. 